\title{
Estimating the Time-of-Involvement of Bulk Packed Lithium-Ion Batteries in a Warehouse Storage Fire
}

\author{
BENJAMIN DITCH*, GEARY YEE, and MARCOS CHAOS \\ FM Global, Research Division \\ 1151 Boston-Providence Turnpike \\ Norwood, MA 02062, USA
}

\begin{abstract}
A novel experimental approach was developed to evaluate the hazard posed by bulk storage of Li-ion batteries in warehouse scenarios. The flammability characteristics of cartoned small-format Li-ion batteries were evaluated via free-burn fire tests of three-tier-high rack storage arrays. For each test, only the ignition flue area of the array was lined with commodity as a means of reducing the required quantity of Li-ion batteries. Effort was placed on measurement of the fire development and, more importantly, the time of significant battery involvement, a key parameter in the hazard analysis of these fires. This parameter was inferred through diagnostics of the convective gas flow, and corroborated with visual observations and analyses of combustion products. For the tests considered herein, Li-ion batteries are shown to contribute significantly to the severity of the storage fires within 5 minutes of ignition.
\end{abstract}

KEYWORDS: Lithium-ion, warehouse fire, hazard assessment

\section{INTRODUCTION}

Since the 1990s, Lithium-ion (Li-ion) batteries have become the rechargeable power supply of choice for consumer electronics [1]. The need for high energy densities has driven the demand for these batteries in devices such as laptops, power tools, cameras, and cell phones. Li-ion batteries present several unique fire hazard challenges compared to traditional battery types. From a fire protection standpoint, the primary concern is the presence of a flammable organic electrolyte within a Li-ion battery compared to the aqueous electrolytes found in other battery types (i.e., nickel metal hydride, nickel cadmium, and lead acid). Under abnormal conditions, such as an external fire, Li-ion batteries have been known to experience thermal runaway reactions resulting in combustion of the ignitable organics and rupture of the battery [2].

The fire hazards inherent to Li-ion battery technology have been a topic of considerable discussion in the fire protection community [3, 4]. Given the emerging nature of this technology, there are currently no known fire protection standards for bulk-storage of Li-ion batteries that are based on real-scale testing. Consequently, the existing approach for protection often relies on designs for high-hazard commodities, e.g., automatic in-rack sprinklers. This approach seems prudent without detailed knowledge of the impact that storage conditions have on the effectiveness of sprinkler protection. The work described herein will consider a common bulk-storage scenario in terms of state of charge (SOC), cell format, packaging and storage arrangement as an initial effort in establishing protection options.

Limited research has focused on the hazards of Li-ion batteries in a scale relevant to actual storage scenarios. Recent work sponsored by the Federal Aviation Administration (FAA) has shown that exposure of individual Li-ion batteries to an external fire can result in violent release and ignition of the stored flammable electrolyte, further fueling the existing fire [5]. Subsequent testing with larger quantities of cartoned Li-ion batteries (5,000 cylindrical cells, 18650-format) showed that the propagation of thermal runaway can occur from cell to cell [6], although this process was slow without the presence of an external fire source. Cell rupture often occurred violently, resulting in substantial flaming projectiles up to $40.5 \mathrm{~m}$ $(133 \mathrm{ft})$ [6]. Ribière et al. [7] showed that the reactivity of Li-ion polymer cells is affected by the SOC. In particular, a fully charged battery has an increased propensity to undergo thermal runaway, increased rate of energy release and, interestingly, decreased total energy release (due to incomplete combustion resulting from the increased reaction rate) [7]. This result suggests that, to reduce the hazard potential in bulk storage, Li-ion batteries should be maintained at a reduced SOC. Current industry practices also place Liion batteries at a reduced SOC. A survey of Li-ion battery manufacturers and distributers concluded that storage at approximately $50 \%$ SOC is optimal for balancing the benefits of reduced cell voltage on calendar aging, while maintaining sufficient capacity to mitigate cell over-discharge when stored for significant periods [4]. Finally, investigations performed at Sandia National Laboratories [8,9] concluded that cells 
containing flammable electrolyte-based chemistries are prone to thermal runaway at temperatures around $180^{\circ} \mathrm{C}\left(356^{\circ} \mathrm{F}\right)$. When applied to a bulk-storage scenario this sets a maximum temperature threshold, which needs to be crossed for battery involvement in a fire. However, given the thermal inertia of the commodity it is not easy to determine the pace of cell to cell propagation.

This study evaluates the flammability characteristics of small format Li-ion batteries in a rack storage array. The tests focus on fire development and time of battery involvement in a free burn fire. From an engineering perspective, the results provide the basis for developing fire protection recommendations. The reliance on free-burn fires allows for a reduction in the amount of test commodity; however, it does not provide the same information as tests that include water application, such as those performed for Commodity Classification [10] or a sprinklered large-scale fire test. The obvious concern for Li-ion battery storage is the additional hazard posed by thermal runaway reactions occurring within the commodity. In a sprinklered fire test, the effectiveness of the protection system on a Li-ion battery fire due to external heating can be evaluated directly. The result is a high level of confidence that the protection system is adequate for the hazard of both the outer carton packaging and the stored Li-ion batteries. Lacking this experience, a more detailed understanding of the fire development is necessary to predict the extent to which Li-ion batteries contribute to the fire severity.

\section{TEST CONFIGURATION}

The test array was designed to capture the fire growth characteristics of a warehouse fire using a reduced amount of commodity. As shown in Fig. 1, the array consists of a three-tier-high, open-frame, single-row steel rack with overall dimensions of approximately $2.4 \mathrm{~m}$ long $\times 1.2 \mathrm{~m}$ wide $\times 4.3 \mathrm{~m}$ tall. To reduce the required quantities of batteries only the ignition flue area of the array is lined with commodity. This array size is used to represent rack storage up to $4.6 \mathrm{~m}$, assuming nominally $1.5 \mathrm{~m}$ per tier.

The bottom tier of the array consists of a noncombustible product (metal liner) supported on a wood pallet. The upper tiers are made of the same noncombustible product lined with test commodity on the flue faces. The noncombustible product is constructed to maintain commodity dimensions of $1.07 \mathrm{~m} \times 1.07 \mathrm{~m} \times$ $1.07 \mathrm{~m}$ and maintain representative airflow around the commodity.

Ignition was achieved with a $0.4 \mathrm{~m}$ diameter propane ring burner centered in the transverse flue $0.15 \mathrm{~m}$ below the second-tier test commodity, see Fig. 1. Propane was supplied at a rate of 30 SLM for the entire test, resulting in a nominal $45 \mathrm{~kW}$ heat release rate.

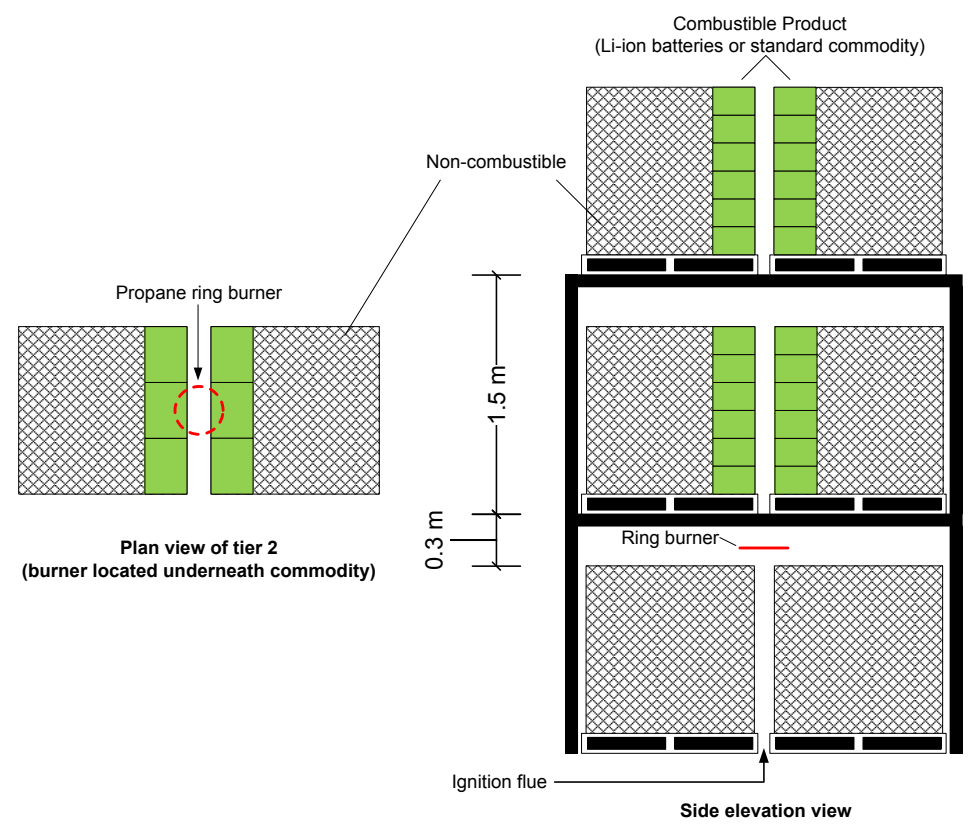

Fig. 1. Schematics of reduced-commodity rack storage test; plan view of tier 2 (left) and side elevation view (right). 


\section{TEST COMMODITY}

Three Li-ion battery types were identified to represent the broad spectrum of commercially available products: 18650-format cylindrical cells, high capacity power tool battery packs, and polymer cells. Specifications for each battery used in this study are shown in Table 1. Figure 2 shows sketches of each individual battery type as well as images in their final packaged state, the packages were arranged as in Fig. 1; further details are provided below.

Table 1. Li-ion battery specifications $[11,12]$

\begin{tabular}{lccc}
\hline & $\begin{array}{c}\text { 18650-Format } \\
\text { Cylindrical }\end{array}$ & $\begin{array}{c}\text { Power Tool Pack } \\
\text { (individual cell) }^{\mathbf{a}}\end{array}$ & Polymer \\
\hline Chemistry & $\mathrm{LiCoO}_{2}$ & $\mathrm{LiNiMnCoO}_{2}$ & $\mathrm{LiCoO}_{2}$ \\
Nominal Voltage (V) & 3.7 & $18.5(3.7)$ & 3.7 \\
Nominal Capacity (mAh) & 2600 & $2600(1300)$ & 2700 \\
Approximate SOC & $40 \%$ & $50 \%$ & $60 \%$ \\
Nominal Weight $(\mathrm{g})$ & 47.2 & $768.5(42.9)$ & 50.0 \\
Electrolyte Weight $(\mathrm{g})$ & 2.6 & $33.0(3.3)$ & 4.0 \\
\hline
\end{tabular}

a The power tool battery packs each contain ten 18650 -format cylindrical cells with a nominal voltage of $3.7 \mathrm{~V}$ and nominal capacity of $1300 \mathrm{mAh}$. The resulting specifications of the power tool pack are a nominal voltage of $18.5 \mathrm{~V}$ and a nominal capacity of $2600 \mathrm{mAh}$.

a)
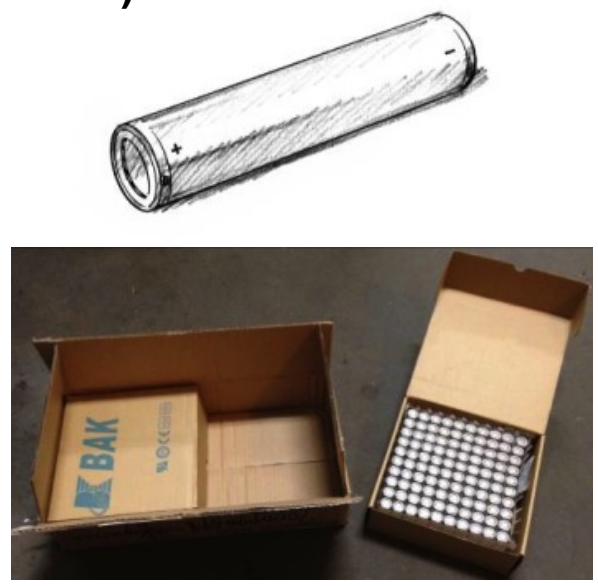
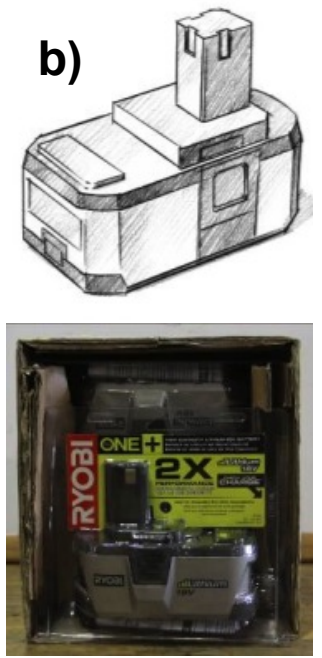

c)

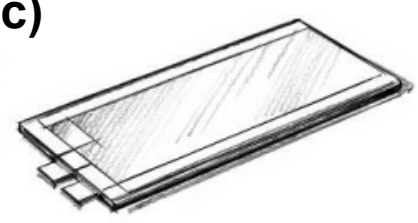

Fig. 2. Diagrams (top) of each individual battery type and carton (bottom) of tested commodity; a) cylindrical cells, b) power tool battery packs, c) polymer cells.

\section{Cylindrical Cells}

The 18650-format cylindrical cell is currently the most widely used battery type and has dimensions of $18 \mathrm{~mm}$ diameter x $65 \mathrm{~mm}$ long. The cell is constructed by winding long strips of electrodes into a "jelly roll" configuration, which is then inserted into a hard metal case and sealed with gaskets. The packaging, as received from the manufacturer, consisted of two $220 \mathrm{~mm} \times 213 \mathrm{~mm} \times 74 \mathrm{~mm}$ inner corrugated board cartons within a $444 \mathrm{~mm} \times 237 \mathrm{~mm} \times 93 \mathrm{~mm}$ outer corrugated board carton (Fig. 2a). Each inner carton contained 100 cylindrical cells separated by paperboard partitions.

The pallet design for the cylindrical cells consisted of cartons received from the manufacturer stacked 12 levels high resulting in dimensions of $1.0 \mathrm{~m} \times 0.22 \mathrm{~m} \times 1.07 \mathrm{~m}$. To maximize the width of the palletized product, the outer corrugated board cartons were cut in half crosswise and placed 4 wide per level, resulting in a total of 24 full cartons ( 48 half cartons) of commodity per pallet (4,800 cylindrical cells). Metal liners were fabricated to fill the remaining portion of the pallet with dimensions of $1.0 \mathrm{~m} \times 0.84 \mathrm{~m} \times 1.07 \mathrm{~m}$. The 
backside of the cartons was metal banded to the metal liner at the fourth and eighth level for additional stability.

Each pallet load of cylindrical cells contained the equivalent of 24 full cartons. When supported on a standard 2-way wood pallet, the combustible weight of the commodity was $53.7 \mathrm{~kg}$; the cartoned Li-ion cylindrical cell commodity contributed $31.3 \mathrm{~kg}$ (corrugated and paper board weighed $18.8 \mathrm{~kg}$ and the cell electrolyte weighed $12.5 \mathrm{~kg}$ ) and the pallet $22.4 \mathrm{~kg}$. The chemical energy for a pallet of the 18650 -format cylindrical cells used in this project is nominally $748 \mathrm{MJ}$, based on the above masses and the heat of combustion for each material (discussed below). The chemical energy of the entire array is 3,548 MJ, i.e., four pallet loads of commodity plus two additional pallets under the first noncombustible tier $(748 \times 4+$ $278 \times 2=3,548 \mathrm{MJ})$.

\section{Power Tool Packs}

The power tool packs are comprised of cylindrical cells encased in a rugged plastic case (Fig. 2b) that measures $140 \mathrm{~mm} \times 82.5 \mathrm{~mm} \times 108 \mathrm{~mm}$. The battery packs are encased in plastic blister packs for display. Each power tool pack contains ten 18650-format cylindrical cells; five cells are connected in series to produce a nominal voltage of $18.5 \mathrm{~V}(3.7 \mathrm{~V}$ per cell $\times 5$ cells in series $)$ and the two sets are then connected in parallel to produce a nominal capacity of $2600 \mathrm{mAh}(1300 \mathrm{mAh}$ per set of 5 cells $\times 2$ in parallel). For simplicity, this pack design is often listed as $48 \mathrm{Wh}(18.5 \mathrm{~V} \times 2.6 \mathrm{Ah}=48.1 \mathrm{Wh})$. The packaging, as received from the manufacturer, consisted of an outer corrugated board carton with dimensions of $203 \mathrm{~mm}$ $\times 203 \mathrm{~mm} \times 210 \mathrm{~mm}$. Each carton contained four power tool packs which were tessellated (staggered) topto-bottom and separated by corrugated board dividers.

The pallet design for the Li-ion power tool packs consisted of manufacturer cartons stacked 5 wide by 5 tall, resulting in dimensions of $1.0 \mathrm{~m} \times 0.15 \mathrm{~m} \times 1.07 \mathrm{~m}$. Each carton was cut in half and fitted with a corrugated board end cap to reduce the number of packs from four to two per carton. A metal liner was fabricated to fill the remaining portion of the pallet with dimensions of $1.0 \mathrm{~m} \times 0.9 \mathrm{~m} \times 1.07 \mathrm{~m}$. The backside of the cartons was metal banded to the metal liner at three elevations for additional stability. This pallet design resulted in 25 half cartons (50 power tool packs) per pallet, containing a total of 500 Li-ion cylindrical cells per pallet.

Each pallet load of power tool packs contained the equivalent of 12.5 full cartons. When supported on a wood pallet, the total combustible weight of a pallet of commodity was $41.0 \mathrm{~kg}$; the cartoned power tool packs contributed $18.6 \mathrm{~kg}$ (corrugated and paper board weighed $6.5 \mathrm{~kg}$, unexpanded plastic weighed 10.4 $\mathrm{kg}$, and the cell electrolyte weighed $1.7 \mathrm{~kg}$ ) and the pallet $22.4 \mathrm{~kg}$. The chemical energy for the pallet design of the power tool packs used in this project is nominally $682 \mathrm{MJ}$, based on the above masses and the heat of combustion for each material. The chemical energy of the entire array is 3,284 MJ, i.e., four pallet loads of commodity plus two additional pallets under the first noncombustible tier $(682 \times 4+278 \times 2=$ $3,284 \mathrm{MJ})$.

\section{Polymer Cells}

Li-ion polymer cells are commonly found in mobile phones and tablet computers and have a soft-case enclosure to reduce the overall size and weight. The polymer cell selected for this project had dimensions of $99 \mathrm{~mm} \times 41 \mathrm{~mm} \times 6 \mathrm{~mm}$. The cells are constructed by winding long strips of electrodes into a "jelly roll" configuration ${ }^{1}$, which is then enclosed in a polymer-coated aluminum pouch with heat-sealed seams. The packaging, as received by the manufacturer, consisted of two $350 \mathrm{~mm} \times 160 \mathrm{~mm} \times 110 \mathrm{~mm}$ inner corrugated board cartons within a $366 \mathrm{~mm} \times 355 \mathrm{~mm} \times 120 \mathrm{~mm}$ outer corrugated board carton. Each inner carton contained 72 cylindrical cells separated by nested clear unexpanded plastic dividers (Fig. 2c).

The pallet design for the Li-ion polymer cells consisted of manufacturer cartons stacked 3 wide by 9 tall, resulting in dimensions of $1.10 \mathrm{~m} \times 0.36 \mathrm{~m} \times 1.07 \mathrm{~m}$. Metal liners were fabricated to fill the remaining portion of the pallet $1.07 \mathrm{~m} \times 0.7 \mathrm{~m} \times 1.07 \mathrm{~m}$ deep. This pallet design resulted in 27 cartons per pallet containing a total of 3,888 polymer cells per pallet. The total combustible weight of the commodity is 79.2 $\mathrm{kg}$; the cartoned Li-ion polymer cell commodity contributed $56.8 \mathrm{~kg}$ (corrugated and paper board weighed $20.7 \mathrm{~kg}$, expanded plastic weighed $0.1 \mathrm{~kg}$, unexpanded plastic weighed $20.4 \mathrm{~kg}$ and cell electrolyte weighed

${ }^{1}$ As opposed to a stacked electrode configuration that is also common for polymer cells. 
$15.6 \mathrm{~kg}$ ) and the pallet $22.4 \mathrm{~kg}$. The chemical energy for a pallet of the polymer cells is nominally $1,393 \mathrm{MJ}$, based on the above masses and the heat of combustion for each material. The chemical energy of the entire array is $6,128 \mathrm{MJ}$, i.e., four pallet loads of commodity plus two additional pallets under the firsttier noncombustible $(1,393 \times 4+278 \times 2=6,128 \mathrm{MJ})$.

\section{Heats of Combustion}

Table 2 contains average chemical heat of combustion (i.e. taking into account combustion efficiency) values, taken from the literature [13, 14], for each major component of the test commodities. These are average values for each material type and up to $5 \%$ variance can be expected with the exception of the Liion battery electrolyte. The heat of combustion value for diethyl carbonate (DEC, $20.9 \mathrm{~kJ} / \mathrm{g}$ [14]) was used as a representative estimate for electrolyte as it has been shown to be similar to other organic carbonate solvents typically found in Li-ion battery electrolyte. In order to determine its chemical heat of combustion, a combustion efficiency of $85 \%$ was assumed, typical of other oxygenated organic solvents [13]. The exact composition of the Li-ion battery electrolytes is unknown, therefore a variance of $20 \%$ was assumed.

Table 2. Chemical heats of combustion for test commodities.

\begin{tabular}{lcc}
\hline \multicolumn{1}{c}{ Material } & $\begin{array}{c}\text { Chemical Heat of } \\
\text { Combustion (kJ/g) }\end{array}$ & $\begin{array}{c}\text { Representative Material } \\
\text { [Reference] }\end{array}$ \\
\hline Wood pallet & $12.4 \pm 0.3$ & Red oak [13] \\
Corrugated and paper board & $13.2 \pm 0.3$ & Corrugated paper [13] \\
Unexpanded plastic & $27.5 \pm 0.7$ & Polystyrene [13] \\
Expanded plastic & $28.0 \pm 0.7$ & Expanded polystyrene [13] \\
Electrolyte & $17.8 \pm 1.8$ & Diethyl carbonate [14] \\
\hline
\end{tabular}

\section{LABORATORY AND INSTRUMENTATION}

Tests were conducted under a 5-MW fire products collector (FPC) at the FM Global Research Campus in West Glocester, Rhode Island, USA. The 5-MW FPC consists of a $6.1 \mathrm{~m}$ diameter inlet that tapers down to a $1.5 \mathrm{~m}$ diameter duct. The inlet to the FPC is at an elevation of $7.9 \mathrm{~m}$ from the floor. Gas concentration, velocity, temperature and moisture measurements are performed within the duct. Beyond the measurement location, the exhaust duct connects to a wet electrostatic precipitator (WESP) prior to the gases venting to the atmosphere. All tests were conducted at a nominal exhaust rate of $1,400 \mathrm{~m}^{3} / \mathrm{min}$.

All instrumentation was calibrated in accordance with ISO 17025 [15]. The following standard instrumentation was installed within the laboratory space and the exhaust duct for the 5-MW FPC: laboratory ambient conditions - temperature, pressure, and relative humidity - were monitored with a Type $\mathrm{K}$, bare-bead, $6.4 \mathrm{~mm}$ sheathed, chromel-alumel thermocouple, a barometric pressure transducer (Setra 270), and a humidity meter (Davis Weather Monitor II), respectively; mass loss was measured with a load cell (Vishay BLH Kis II with LCP-104-VR3-20 controller) located under each corner of a platform supporting the rack structure; non-dispersive infrared (NDIR) $\mathrm{CO}$ and $\mathrm{CO}_{2}$ gas analyzers to measure the generation of carbon monoxide and carbon dioxide; a paramagnetic $\mathrm{O}_{2}$ analyzer to measure depletion of oxygen; a flame ionization detector (FID) total hydrocarbon (THC) analyzer to measure the release of volatile organic compounds (VOC); and a flow meter (Hasting HMF 301) and manual metering valves to monitor and control the propane flow to the ring burner.

In addition to the measurement devices listed above, Fourier Transform Infrared (FTIR) spectroscopic analyses were also performed on the FPC exhaust in an effort to further determine the emission characteristics of the Li-ion battery fires. Samples were extracted from the FPC exhaust by a heated diaphragm pump through a heated stainless steel probe and glass fiber particulate filter. The extracted flow was directed via a heated Teflon transfer line to a MKS MultiGas ${ }^{\text {TM }} 2030$ FTIR Continuous Gas Analyzer fitted with a $5.11-\mathrm{m}$ multipass cell heated to $150^{\circ} \mathrm{C}$. Data were collected at $0.5 \mathrm{~cm}^{-1}$ resolution as the coaddition of 54 scans, resulting in a sample integration time of 32 seconds (nominal). With this arrangement measurements of small saturated and unsaturated hydrocarbons (e.g. ethane, ethylene) were made along with small ketones, aldehydes, and alcohols (e.g. acetone, formaldehyde, methanol) as well as nitrogen oxides, sulfur oxides, and hydrogen chloride. These species, especially the oxygenated hydrocarbons, were 
chosen as these could stem from the incomplete burning of battery electrolyte, possibly providing an indication of battery involvement. It is noted that FTIR data were only collected for tests involving the cylindrical cells or power tool packs commodities.

\section{CONVECTIVE HEAT RELEASE RATE (HRR) AND SPECIES EMISSION CHARACTERISTICS}

The convective heat release rates, determined from the temperature rise of the flow in the FPC, for each commodity are shown in Fig. 3. To simplify the comparison, the time of each test has been slightly offset to align the initial fire growth period. Each commodity exhibits a similar initial fire growth as the flames spread vertically along the corrugated board cartons that line the fuel space above ignition. The fire development for each commodity is detailed below. Due to the prohibitive nature (in terms of commodity cost and availability) of performing repeat tests with Li-ion batteries, repeatability of the fire development was assessed by conducting tests with class 2 commodity (i.e. a metal liner surrounded by three layers of double-wall corrugated cardboard) arranged in the same configuration as in Fig. 1. Figure 4 shows the measured convective heat release rates for three repeat tests. The initial convective fire growth agrees well for all three tests over the first $80 \mathrm{~s}$, which corresponds with vertical fire spread along the cartons. Subsequent involvement of the wood pallets and consumption of the cartons result in a leveling off of the heat release rate, with an approximately $20 \%$ variation among the tests, until the tests were terminated.

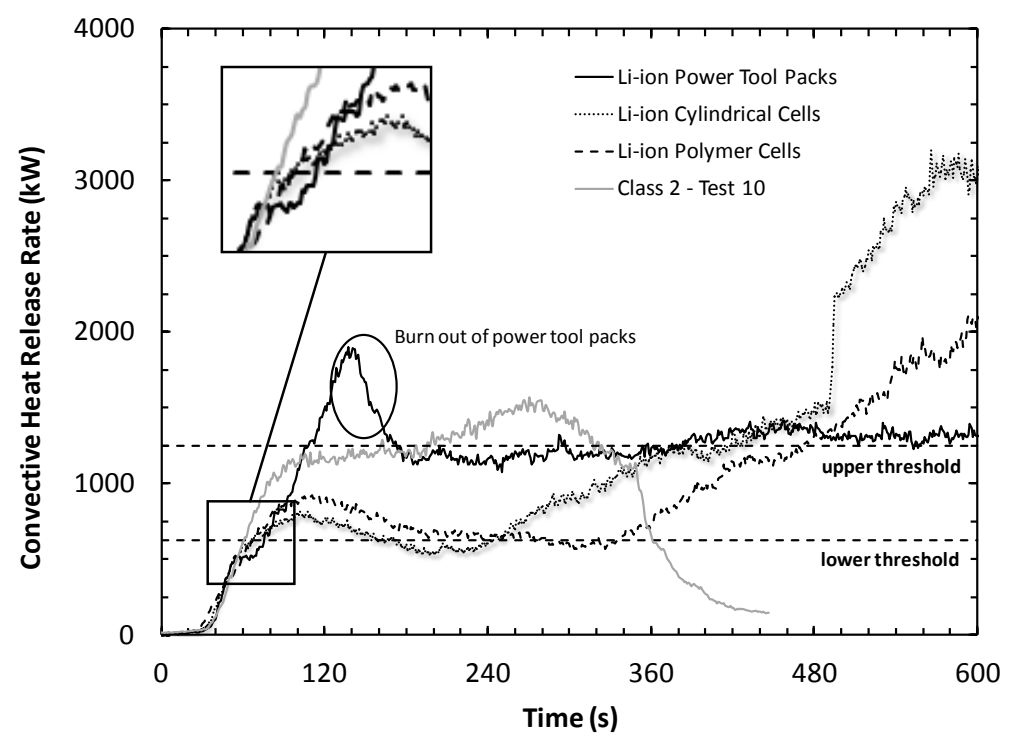

Fig. 3. Convective heat release rates for Li-ion battery tests. The convective heat release rate for a Class 2 commodity (see Fig. 4) fire is also shown for comparison.

Li-ion cylindrical cells exhibited a steady increase in the initial growth until a peak value of $790 \mathrm{~kW}$ was achieved at $110 \mathrm{~s}$ (see Fig. 3). The fire size then declined to a value of $535 \mathrm{~kW}$ at $200 \mathrm{~s}$ due to consumption of the carton packaging and to a lesser extent energy spent to heat the cells and vaporize battery contents. Subsequent contributions from the wood pallets and Li-ion cells resulted in consistent fire growth until the fire reached a maximum of about $3,900 \mathrm{~kW}$ at $690 \mathrm{~s}$. The jump in fire size at $490 \mathrm{~s}$ was a result of product collapse. Manual fire suppression began at 1,000 s approximately (not shown in Fig. 3).

Li-ion power tool packs exhibited a delay in fire growth at $55 \mathrm{~s}$ as the flames penetrated the cartons and the plastic components of the battery packs became involved in the fire. This delay was observed as a temporary plateau in the heat release curve from $55 \mathrm{~s}$ to $75 \mathrm{~s}$ (Fig. 3). The fire then grew steadily from $75 \mathrm{~s}$ to $137 \mathrm{~s}$ until a maximum value of $1,900 \mathrm{~kW}$ was reached. The fire then decreased to nominal steady-state value of $1,250 \mathrm{~kW}$ at $180 \mathrm{~s}$ as the power tool packs were consumed, leaving only the wood pallets. The fire then remained steady until $600 \mathrm{~s}$ when the fire size slowly tapered off as the combustibles were consumed. It is important to note that the power packs began sporadically falling off the array at $64 \mathrm{~s}$, with an estimated 20 packs falling over a $30 \mathrm{~s}$ period, and a larger collapse occurring at $105 \mathrm{~s}$. It is not expected that these collapses significantly affected the fire growth before about $90 \mathrm{~s}$ after ignition due to the small percentage of the overall packs having collapsed. Manual fire suppression began at 2,750 s. 


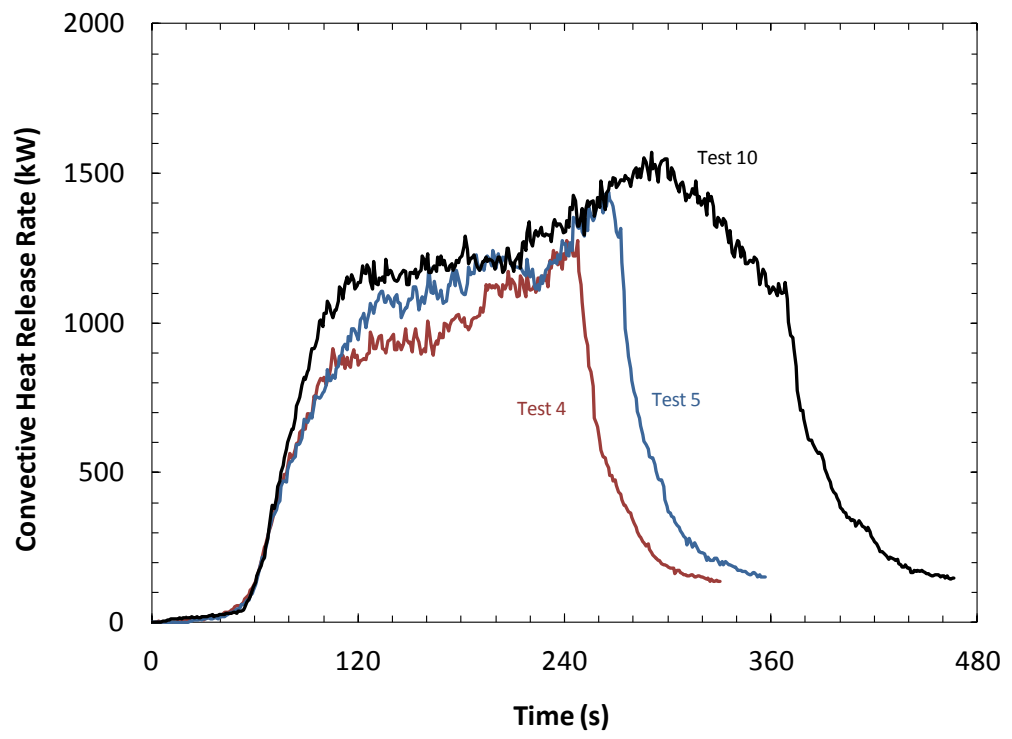

Fig. 4. Test repeatability assessment using FM Global standard class 2 commodity.

The Li-ion polymer cells exhibited a fire development similar to the cylindrical cell. For the polymer cells, the fire grew until a peak value of $920 \mathrm{~kW}$ was achieved at $110 \mathrm{~s}$ (Fig. 3). The fire size then declined to a value of $570 \mathrm{~kW}$ at $305 \mathrm{~s}$ due to consumption of the carton packaging. Subsequent contributions from the wood pallets and Li-ion cells resulted in consistent fire growth until the fire reached a maximum of $3,800 \mathrm{~kW}$ at $750 \mathrm{~s}$. A minor product collapse occurred at $515 \mathrm{~s}$ followed by a major collapse at $540 \mathrm{~s}$. Manual fire suppression began at $910 \mathrm{~s}$.

These data provide several key comparison points relative to the hazard posed by each commodity. First, the agreement of the heat release rates resulting from the initial vertical fire spread supports the assumption that cartoned commodities exhibit similar fire development for three-tier high rack storage. Further evidence of the validity of this assumption is provided in Fig. 3 by comparison of the convective heat release rates for the Li-ion battery fires to that measured for a class 2 commodity fire (involving only corrugated cardboard boxes); initial fire growth (up to $60 \mathrm{~s}$ ) is nearly identical for all tests. Subsequent breach of the cartons highlights the impact of the stored contents. For cartons containing significant quantities of loosely packed plastics (i.e., Li-ion power tool packs), involvement of the plastic results in a rapid increase in the released energy early in the fire development. For cartons containing densely packed Li-ion batteries and minimal plastics (i.e., Li-ion cylindrical and polymer cells), the fire growth is delayed several minutes until the batteries become significantly involved.

Figures 5 and 6 show species yield data (only those species present in amounts above detectable thresholds, $0.25 \mathrm{ppm}$ on average, are shown) for tests involving cylindrical cells and power tool packs, respectively. The yields were calculated from the mass flow rate for a given species measured in the FPC normalized by the mass loss rate obtained from load cell measurements. For consistency, all data shown are those measured by the FTIR although it is noted that these data are in good agreement with those for common species (i.e., $\mathrm{CO}$ and $\mathrm{CO}_{2}$ ) obtained from the NDIR analyzers.

Major stable species $\left(\mathrm{CO}_{2}, \mathrm{CO}, \mathrm{H}_{2} \mathrm{O}\right)$ shown in Figs. 5a and 6a exhibit a transient followed by a relatively steady state behavior. In the case of the power tool packs an increase in the $\mathrm{CO}_{2}$ yield is observed due to involvement in the fire of the plastic materials as they contain more carbon than other test material listed in Table 2. In Figs. 5b and 6b, the organic compounds shown amount to over $90 \%$ of the total hydrocarbons measured by the THC analyzer, indicating that small molecules make up the majority of species generated due to incomplete combustion. After manual water application, however, this agreement does not hold, as expected since copious amounts of large hydrocarbons (e.g., in the form of smoke) are generated. Note that alcohol species are observed in the cylindrical cells test as opposed to the power tool packs test. On the other hand, acetaldehyde and considerable amounts of hydrochloric acid are present during the power tool packs test. The latter species is due to chlorinated compounds used in the plastic packaging of the power 
tool packs. Dimethyl carbonate was also observed during the cylindrical cell test (not included in Fig. 5b), which is a common component of cell electrolyte; however, not until after manual water application.
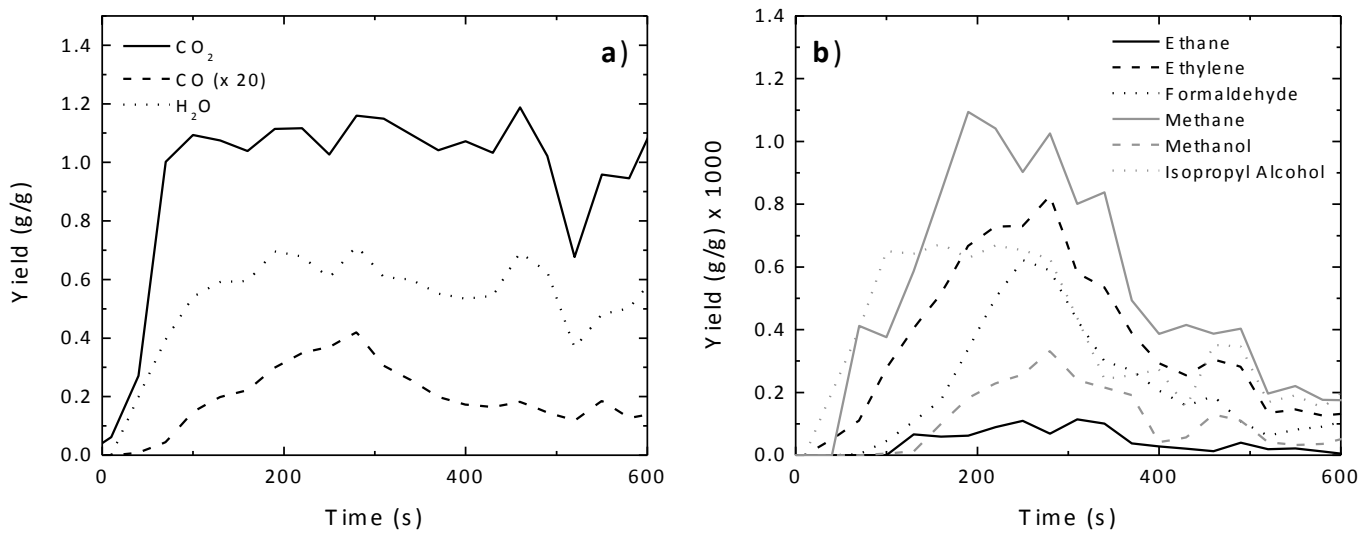

Fig. 5. Species yields for the cylindrical cells test; a) major combustion species; b) relevant organic compounds.
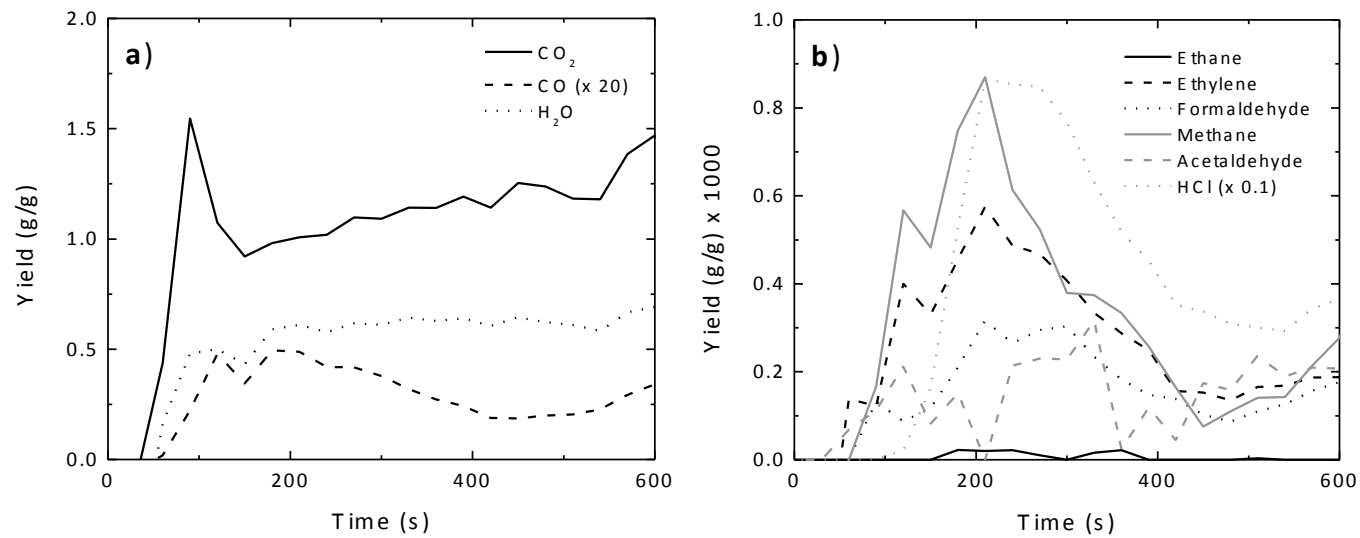

Fig. 6. Species yields for the power tool pack test; a) major combustion species; b) relevant organic compounds and hydrochloric acid $(\mathrm{HCl})$.

\section{TIME OF BATTERY INVOLVEMENT}

For the purpose of this study, battery involvement references the time during the fire development where the batteries are observed to contribute significantly to the fire severity. In the warehouse storage fire scenario used in this study, the determination of battery involvement is complicated by the large quantities of combustible components that comprise the test commodities; including, wood pallets, corrugated board cartons, and plastic packaging. Several approaches were investigated here to establish the time of battery involvement; analysis of the convective heat release rate measurement was found to be the most reliable and is detailed below.

Each rack storage test was conducted with a reduced quantity of commodity supported on a standard-sized wood pallet. During the class 2 commodity and Li-ion power tool pack tests, the majority of the test commodity was consumed during the initial fire growth. The subsequent nominal steady-state HRR of $1,250 \mathrm{~kW}$ (see Fig. 3) was a result of combustion of the wood pallets on the second and third tier $(1,250 \mathrm{~kW} / 4 \text { pallets }=312.5 \mathrm{~kW} / \text { pallet })^{2}$. Since the contribution from the wood pallets should be the same for all tests, it is reasonable to attribute any increase in the heat release rate to combustion of the Li-ion batteries. Therefore, $1,250 \mathrm{~kW}$ represents the upper threshold value (after the initial fire growth) corresponding to the latest time in the fire development where the batteries are not contributing to the

${ }^{2}$ The energy released per pallet is consistent with a previous internal study that indicated the steady-state convective heat release rate for a wood pallet ranges between $250 \mathrm{~kW}$ to $300 \mathrm{~kW}$ in a rack storage array. 
overall fire severity. As shown in Fig. 3, the convective HRR for Li-ion cylindrical cells and polymer cells exceeded 1,250 kW (upper horizontal dashed line) at $385 \mathrm{~s}$ and $470 \mathrm{~s}$, respectively. No estimate can be made for the power tool packs due to the added combustible load related to the plastic components.

The time of battery involvement can also be estimated at an earlier stage in the fire development. During the Li-ion cylindrical cell and polymer cell tests, after the initial vertical flame spread along the cartoned packaging, the convective HRR steadily decreased to a nominal minimum value of $600 \mathrm{~kW}$ at $200 \mathrm{~s}$ and 305 s, respectively (see Fig. 3). Visual observations show the wood pallets on the $3^{\text {rd }}$ tier (i.e., two pallets) were the predominant combustible involved in the fire, which is consistent with the $312.5 \mathrm{~kW}$ per pallet estimate established above from the class 2 commodity and Li-ion power tool pack tests. The fire size then steadily increased to the upper threshold value of $1,250 \mathrm{~kW}$; however, in both tests, the wood pallets on the second tier were only partially involved in the fire, suggesting involvement of the Li-ion batteries. The exact contribution from the wood pallets and batteries to the fire severity cannot be further differentiated. Therefore, $625 \mathrm{~kW}$ represents the lower threshold HRR (after the initial fire growth) corresponding to the earliest time in the fire development where the batteries are contributing to the overall fire severity.

Using the upper and lower threshold values, involvement of the Li-ion cylindrical cells occurred between $240 \mathrm{~s}$ and $385 \mathrm{~s}$ and involvement of the Li-ion polymer cells occurred between $305 \mathrm{~s}$ and $470 \mathrm{~s}$. Taking the average of these values and rounding down to the nearest minute results in a nominal time of battery involvement of $300 \mathrm{~s}$ after ignition, under free-burn fire conditions. The upper and lower threshold values indicating Li-ion battery contribution to the fire severity are applicable only to the tests configuration used in this project.

In this study, detailed species emission data were collected in the hope that a chemical signature would clearly identify battery involvement in the fire. Such chemical signature would specifically involve species that could be generated only from combustion of battery components, i.e. the battery electrolyte. As shown in Figs. 5a and 6a species typically measured by calorimetry methods do not provide such a clear assessment. For example both $\mathrm{CO}_{2}$ and $\mathrm{H}_{2} \mathrm{O}$ yields reach steady values that are consistent with the stoichiometric yields of these species reported for cellulosic materials [13]. Other approaches were also investigated such as considering the ratio of $\mathrm{CO}_{2}$ generation and oxygen consumption rates; given the organic nature of the combustible materials (see Table 2) it is noted that this ratio would be similar for all materials. Figure 5b, however, shows that for a test with considerable battery involvement an increased yield of alcohol species can be observed; i.e., methanol and isopropyl alcohol were observed for the cylindrical cells test but not for the power tool packs test (compare Fig. 5b and $6 \mathrm{~b}$ ). These alcohols are likely to stem from the carbonate species in the battery electrolyte. The ester moiety contained within carbonate solvents can give rise to the formation of alcohols. Involvement of carbonate species in the fire is further supported by the increased yield of methane and ethane in the cylindrical cells test as opposed to the battery tool packs test (see Figs. 5b and 6b). The increased yield of these species also suggests an increase in the yield of methyl radicals (which can recombine to form ethane and methane) due to direct decomposition of carbonate species.

On the basis of the above discussion, it is noted that the yields of alcohols, methane, and ethane species peak at approximately $300 \mathrm{~s}$ in Fig. 5b. This value is in agreement with the time estimated for battery involvement by analyzing the convective heat release trends. Despite the observed consistency, the species analyses above are still qualitative and likely to be inapplicable to other scenarios as the species identified can be formed from the combustion of many different fuels. A chemical signature exclusively associated with a component within the battery would be needed to unambiguously determine the time of battery involvement which was not found in this study.

\section{CONCLUSION}

The flammability characteristics of cartoned Li-ion batteries have been studied in a bulk packed warehouse storage scenario via free-burn fire tests. A novel experimental approach allowed for a reduction in the quantity of batteries while maintaining the fire growth characteristics necessary to estimate the time of battery involvement. For each test, the ignition flue of a three-tier-high rack storage array was lined with Li-ion batteries. The specific batteries tested were cylindrical cells, power tool packs containing cylindrical cells, and polymer cells. Measurement of the convective heat release rates showed the densely packed cylindrical cells and polymer cells batteries contributed significantly to the severity of the storage fires 
within five minutes of ignition. No estimate could be made for the power tool packs due to the added combustible load related to the plastic components. These results were corroborated with visual observations. Species emission data for the cylindrical cells qualitatively support the estimate of battery involvement through increased levels of oxygenated hydrocarbons attributed to the combustion of carbonate species in the battery electrolyte; though a chemical signature exclusively associated with a component within the battery could not be identified. One likely species, dimethyl carbonate, was only observed after fire suppression water was applied to terminate the tests.

This study provides the basis for the long-term goal of establishing research-based fire protection options to the unique hazards associated with Li-ion batteries in storage occupancies. It is important to note that the combined effects of storage height, ignition scenario, Li-ion battery type - format, capacity, and SOC - are yet to be well understood and may impact the time of battery involvement. Whereas the scope of the present study does not extend to hazard classification or design of protection systems, it is worth noting that data presented herein were further analyzed and compared to those available for other commodities [11]. Based on these comparisons, cylindrical and polymer cells exhibited burning characteristics of high hazard commodities due primarily to the contribution of the cell electrolyte to the fire severity. Li-ion power tool battery packs exhibited burning characteristics similar to cartoned unexpanded plastic commodity due to the relative large quantity of plastic compared to the quantity of cell electrolyte. Furthermore, predictions of sprinkler time activation [11] showed that, under the conditions of the present study, a properly designed sprinkler system can activate before the Li-ion batteries become significantly involved.

\section{ACKNOWLEDGEMENTS}

The authors are grateful to Drs. Louis A. Gritzo, Sergey B. Dorofeev, and Christopher J. Wieczorek for their valuable insight and support of this work, and the efforts of the talented staff at the FM Global Research Campus in conducting the tests are truly appreciated. The authors further thank Kathleen Almand, as head of the Fire Protection Research Foundation, and the members of the Property Insurance Research Group for their insightful discussions. In addition, the funding provided by PIRG members and additional sponsors for the Li-ion batteries was essential to the economic feasibility of this project.

\section{REFERENCES}

[1] Lisbona, D. and Snee, T., (2011) A Review of Hazards Associated with Primary Lithium and Lithium-ion Batteries, Process Safety and Environmental Protection 89: 434-442, http://dx.doi.org/10.1016/j.psep.2011.06.022

[2] Arbizanni, C., Gabrielli, G., and Mastragostino, M. (2011) Thermal Stability and Flammability of Electrolytes for Lithium-ion Batteries, Journal of Power Sources 196: 4801-4805, http://dx.doi.org/10.1016/j.jpowsour.2011.01.068

[3] Buser, M., (2011) "Lithium Batteries: Hazards and Loss Prevention," S+S Report International, Oct., pp. 10-17, http://vds.de/fileadmin/report/sus report 2011-10en.pdf

[4] Long, R.T., Kahn, M., and Mikolajczak, C., (2012) "Lithium-Ion Battery Hazards," Fire Protection Engineering, Oct. 7, pp. 20-36, http://magazine.sfpe.org/content/lithium-ion-batteryhazards

[5] Summer, S.M., (2010) "Flammability Assessment of Lithium-Ion and Lithium-Ion Polymer Battery Cells Designed for Aircraft Power Usage,”, U.S. Department of Transportation Federal Aviation Administration Report DOT/FAA/AR-09/55, Springfield, VA, 2010, http://www.fire.tc.faa.gov/pdf/09-55.pdf

[6] Webster, H., (2012) "Preliminary Full-Scale Fire Tests with Bulk Shipments of Lithium Batteries," 2012 FAA Fire Safety Highlights, U.S. Department of Transportation Federal Aviation Administration, http://www.fire.tc.faa.gov/pdf/2012Highlights.pdf

[7] Ribière, P., Grugeon, S., Morcrette, M., Boyanov, S., Laruelle, S., and Marlair, G., (2012) Investigation on the Fire-Induced Hazards of Li-ion Battery Cells by Fire Calorimetry, Energy and Environmental Science 5: 5271-5280, http://dx.doi.org/10.1039/c1ee02218k 
[8] Roth, E.P., Crafts, C., Doughty, D.H., and McBreen, J., “Advanced Technology Development Program for Lithium-Ion Batteries: Thermal Abuse Performance of 18650 Li-Ion Cells," Sandia National Laboratories Report SAND2004-0584, Albuquerque, NM, 2004, http://prod.sandia.gov/techlib/access-control.cgi/2004/040584.pdf

[9] Abraham, D.P., Roth, E.P., Kostecki, R., McCarthy, K., and Doughty, D.H., (2006) Diagnostic Examination of Thermally Abused High-Power Lithium-ion Cells, Journal of Power Sources 161: 648-657, http://dx.doi.org/10.1016/j.jpowsour.2006.04.088

[10] Xin, Y. and Tamanini, F., (2008) Assessment of Commodity Classification for Sprinkler Protection Using Representative Fuels, Fire Safety Science 9: 527-538, http://dx.doi.org/10.3801/IAFSS.FSS.9-527

[11] Ditch, B. and de Vries, J., "Flammability Characterization of Lithium-ion Batteries in Bulk Storage," FM Global Research Technical Report, March 2013, http://www.fmglobal.com/researchreports

[12] Long, R.T., Sutula, J., and Kahn, M., "Li-ion Batteries Hazard and Use Assessment Phase IIB: Flammability Characterization of Li-ion Batteries for Storage Protection," Prepared for Fire $\begin{array}{llll}\text { Protection } & \text { Research } & \text { Foundation, } & \text { April, }\end{array}$ http://www.nfpa.org/assets/files//Research\%20Foundation/RFLithiumIonBatteriesIIB.pdf

[13] Tewarson, A. "Generation of Heat and Chemical Compounds," The SFPE Handbook of Fire Protection Engineering ( $4^{\text {th }}$ ed), DiNenno, P.J. (ed), National Fire Protection Association, Quincy, MA, 2008, pp. 3-109 to 3-194.

[14] Harris, S.J., Timmons, A., and Pitz, W.J., (2009) A Combustion Chemistry Analysis of Carbonate Solvents in Li-Ion Batteries, Journal of Power Sources 193: 855-858, http://dx.doi.org/10.1016/j.jpowsour.2009.04.030

[15] International Standards Organization (ISO/IEC) 17025:2005, General Requirements for the Competence of Testing and Calibration Laboratories, International Standards Organization, Geneva, Switzerland, 2005. 